\title{
DIFLUBENZURON FOR PORINA CONTROL IN OTAGO
}

\author{
C.M. FERGUSON, P.A. JONES and B.I.P. BARRATT
}

MAFTech Invermay Agricultural Centre, Private Bag, Mosgiel

\section{SUMMARY}

The insect growth regulator diflubenzuron was used in a trial to control porina on the coastal Otago plateau. It was applied at the manufacturer's recommended rate of $12.5 \mathrm{~g} / \mathrm{ha}$ in 200 litres of water/ha in late March 1988. Porina population density was estimated by soil sampling immediately prior to treatment and 6 and 19 weeks after treatment. It was found to have been significantly reduced porina density 6 weeks after treatment. It was concluded that diflubenzuron may have a role to play in porina control in Otago but further experimentation is recommended.

\section{INTRODUCTION}

The insect growth regulator diflubenzuron has been shown in some North Island trials (Wrenn et al 1985) to be a more cost effective method of controlling porina (Wiseana spp), than the more conventional organophosphate insecticides. However, in trials in South Otago (Stewart and Ferguson 1989) it failed to give consistently significant control of porina, the most important pasture pest in Otago and Southland. The reasons for this are not known although species composition of porina populations may be partly responsible. Insect growth regulators are more environmentally acceptable than conventional insecticides and potentially cheaper. Because of these positive aspects and the limited amount of research in the southern South Island this trial aimed to reassess the effectiveness of diflubenzuron in controlling porina.

\section{METHOD}

At 10 sites spread over two paddocks on a beef cattle and sheep farm at Clarks (soil type Wehenga silt loam) on the coastal Otago plateau near Outram, diflubenzuron was applied (Dimilin $25 \mathrm{~W}$ ), at the manufacturer's recommended rate $(12.5 \mathrm{~g} / \mathrm{ha}$ in 200 litres water/ha) to $20 \mathrm{~m} \mathrm{x} 2 \mathrm{~m}$ plots. Adjacent areas of the same size were used as control plots. Diflubenzuron was sprayed on close cropped $(5 \mathrm{~cm})$ grass/clover pastures on 21 March (sites 1 - 5) and 28 March 1988 (sites 6 - 10) using a gas operated back pack sprayer. Porina population density was estimated immediately prior to spraying by taking five $0.0225 \mathrm{~m}^{2}$ quadrats of soil $20 \mathrm{~cm}$ deep per plot. The larvae from the top $3 \mathrm{~cm}$ of each spit were extracted in Berlese funnels in a laboratory while the soil below $3 \mathrm{~cm}$ was hand sorted in the field. All larvae found were counted and their length measured. Post-treatment sampling 44 days after treatment was carried out by digging ten $0.1 \mathrm{~m}^{2}$ quadrats of soil $30 \mathrm{~cm}$ deep per plot. Larvae from the top $3 \mathrm{~cm}$ were heat extracted in the laboratory as above and the remainder of each sample hand sorted in the field. Nineteen weeks after treatment, five sites with the highest porina densities were sampled again in the same manner, except that the $3 \mathrm{~cm}$ turf layer was also hand sorted. The data were subjected to an anlysis of variance using pre-treatment counts as covariates.

\section{RESULTS AND DISCUSSION}

Generally low populations of porina were encountered in this trial. Only two sites had high initial populations ( 70 and $80 \mathrm{larvae} / \mathrm{m}^{2}$ ) and both suffered natural decline during the trial.

Of the larvae found during pre-treatment sampling, 97\% were in the top $3 \mathrm{~cm}$ of soil and $99 \%$ were less than $25 \mathrm{~mm}$ long (range $4-30 \mathrm{~mm}$, mean $=11.6(\mathrm{SEM}=0.8)$ ). On this basis, timing of diflubenzuron application was ideal according to label recommendations. Despite this, post-treatment sampling in May showed an average reduction of only $40 \%(\mathrm{P}<0.05)$ of porina in the diflubenzuron treated plots relative to Proc. 42nd N.Z. Weed and Pest Control Conf. 
TABLE 1: Effect of diflubenzuron on porina numbers $/ \mathrm{m}^{2}$ (adjusted for covariates)

\begin{tabular}{lccc}
\hline & Pre-treatment & \multicolumn{2}{c}{ Post-treatment } \\
& March & May & *August \\
\hline untreated & 28.6 & 14.6 & 29.6 \\
diflubenzuron & 22.3 & 8.8 & 15.8 \\
\hline SED & & 2.48 & 10.31 \\
\hline
\end{tabular}

*Five sites with highest population densities.

the untreated plots (Table 1). Sampling of five sites with the highest densities in August indicated that there were $47 \%$ fewer porina in the diflubenzuron plots compared to the untreated plots but this difference was not significant (Table 1).

The level of control of porina provided by diflubenzuron in this trial is unlikely to appeal to farmers. However $40 \%$ control of a marginally damaging population (i.e. 30 to 40 porina $/ \mathrm{m}^{2}$ ) may be cost effective and would assist natural disease build up by retaining a low population of larvae. In this respect, and because a positive result lends some support to the sporadic success of Stewart and Ferguson (1989), diflubenzuron, and other insect growth regulators, should be more fully evaluated in this region and reasons for its poor performance identified.

\section{CONCLUSION}

Diflubenzuron at the recommended rate caused only a $40 \%$ reduction of porina but, because of its relatively low price, may be a viable option in situations where low porina populations preclude the use of more expensive organophosphate insecticides.

\section{ACKNOWLEDGEMENTS}

The authors would like to thank Mr K. Marsh for his assistance, Mr I. Nichol for use of his land and Mr P.D. Johnstone for the statistical analysis.

\section{REFERENCES}

Stewart, K.M. and Ferguson, C.M., 1989. Porina control in South Otago sheep pastures. N.Z. J. Agric. Res. (in press).

Wrenn, N.R., McGhie, R.A. and Pottinger, R.P., 1985. Bioassay and field experiments for evaluation of difluron for porina caterpillar control in pasture. Proc. 4th Australasian Conf. on Grassland Invert. Ecol.: 286-292. 